Crafting Divine Personae in Julian's Oration 7

Author(s): David Neal Greenwood

Source: Classical Philology, Vol. 109, No. 2 (April 2014), pp. 140-149

Published by: The University of Chicago Press

Stable URL: http://www.jstor.org/stable/10.1086/675618

Accessed: 18/08/2015 05:01

Your use of the JSTOR archive indicates your acceptance of the Terms \& Conditions of Use, available at http://www.jstor.org/page/info/about/policies/terms.jsp

JSTOR is a not-for-profit service that helps scholars, researchers, and students discover, use, and build upon a wide range of content in a trusted digital archive. We use information technology and tools to increase productivity and facilitate new forms of scholarship. For more information about JSTOR, please contact support@ jstor.org. 


\title{
CRAFTING DIVINE PERSONAE IN JULIAN'S ORATION 7
}

\author{
DAVID NEAL GREENWOOD
}

I N THE SPRING OF 362, the Cynic Heracleios had delivered an offensive lecture in the Emperor Julian's court in Constantinople, playing the role of Zeus chastising the emperor as Pan (Julian Or. 7.234cd). ${ }^{1}$ Julian responded swiftly with To the Cynic Heracleios, in which he included his plan for action regarding Constantine's Christianization of the empire. ${ }^{2}$ In Julian's oration, Helios instructed the young emperor "to cleanse all the impiety"

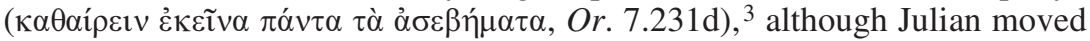
well beyond the justification for a housecleaning. I will demonstrate the extent of Julian's synthesis, making use of pagan elements of emperor worship, his family association with the gods Helios and Heracles, and features co-opted from Christian theology in order to present himself as both a prophetic guide to paganism and a pagan son of god rivaling Christ and Constantine. ${ }^{4}$

Julian first laid the groundwork at Oration 7.219d-220a by re-crafting the divine hero Heracles into the image of Christ. ${ }^{5}$ Julian's revised version of Heracles had developed many Christ-like attributes, including demonstrating control of the elements through a miraculous ability to walk on water: "but I

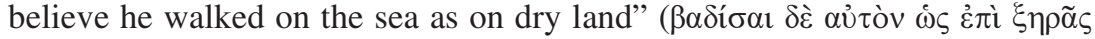

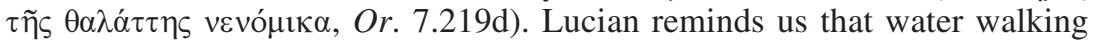
to pagans suggested magic (Philops. 13), but in Julian's hands Heracles was able to walk on water specifically because the elements were controlled by his immaculate mind and divine body. ${ }^{6}$ This is paralleled in the Christian Scriptures in a pericope found in three gospels (Matt. 14:22-33, Mark 6:45-52,

I am grateful for the helpful comments of Gavin Kelly, Sara Parvis, Lucy Grig, Calum Maciver, and the two anonymous $C P$ reviewers. The translations are my own unless otherwise noted.

1. Cf. Rochefort 1963, 36; Smith 1995, 89; Guido 2000, viii. Julian mentions that Heracleios profaned Helios and wrote of someone (presumably himself) being cast as Phaethon (Or. 7.208ab). From this, Athanassiadi (1981, 131-32) plausibly reconstructs Heracleios' allegory as a parody of Julian as the inept son of Helios trying to drive his father's chariot.

2. Rosen $(2006,57)$ refers to this as the revealing of Julian's state program (Regierungsprogramm) embedded in a mythic personal narrative. Julian reportedly composed his response in a single night, and internal evidence suggests that it too was delivered publicly (Lib. Or. 18.157; Julian Or. 7.205b, 235a); Smith 1995, 49; Marcone 2012, 240. The claim of composition in one night should be qualified by the sophisticated layers of the work, suggesting that we may be dealing with the panegyrical topos of a composition tossed off quickly with great facility; cf. Lib. Or. 12.94.

3. I use the Budé numbering system and Greek text (from Rochefort 1963) for Julian's works throughout.

4. Regarding the terminology "pagan," I realize keenly the imperfect nature of this term, although the other choices seem equally problematic.

5. Heracles is a significant choice, as the national god of Hellenism, and "the Roman hero par excellence." Athanassiadi 1981, 133, 197; cf. Livy 1.7; Verg. Aen. 8.102-304.

6. Guido 2000, 142-43.

Classical Philology 109 (2014): 140-49

[C 2014 by The University of Chicago. All rights reserved] 0009-837X/14/10902-0003\$10.00 
John 6:16-21), wherein Christ was seen walking on the water $(\pi \varepsilon \rho \iota \pi \alpha \tau o \tilde{v} \nu \tau \alpha$

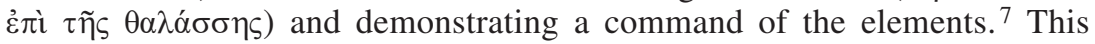
caused his disciples to worship him as divinity (Matt. 14:33), a divine recognition based on the recalling of God's creative power over the elements (Gen. 1) and his control over the parting of the Red Sea (Exod. 14-15).

Most significantly, Heracles was now begotten to be the savior of the world. Heracles, originally the son of Alcmene and Zeus via sexual intercourse, became the son of Athena the virgin goddess and Zeus, whom Julian in Neoplatonic fashion equated with Helios. ${ }^{8}$ Julian explained the origins and purpose of the new-model Heracles: "Him great Zeus begat to be the savior of the world through Athena who is forethought, and placed as guardian over him this goddess he had brought forth whole from the whole of himself"

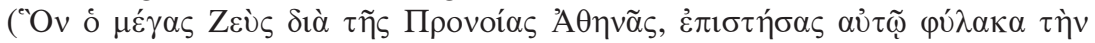

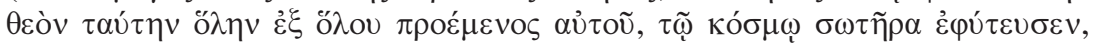
Or. 7.220a). ${ }^{9}$ This new begetting for Heracles recalled Christ's virgin birth in the gospels and the early third-century Roman Creed (cf. Matt. 1:18-23, Luke 1:26-35). ${ }^{10}$ While the title $\sigma \omega \tau \eta \dot{~} \rho$ had been used to describe rulers from Ptolemy to Augustus (OGI 458), the term had also become a fixed theological title for Christ by the close of the first century. Julian's statement here that Heracles was begotten to be the savior of the world is quite close to that found in the New Testament, which stated, "the Father has sent his son to be the

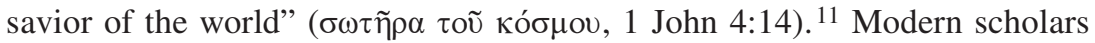
are aware that Julian's presentation here is at least unusual, although their comments range from footnotes to brief summaries. ${ }^{12}$

Both Heracles and Zeus-Helios had relationships with the Constantinian dynasty and were key figures in the imperial cult. Diocletian had given members of the Tetrarchy relationships with the gods Jupiter and Hercules, creating "Jovian" and "Herculian" lines in which the earthly rulers were mimetic images of the divine, a father/son relationship that Marcel Simon has argued was a deliberate engagement with Christianity. ${ }^{13}$ From Julian's perspective, Constantius I's son Constantine was an apostate Herculian, who had abandoned the worship of Helios for the Christian God, whereas Constantius I's

7. The text of the New Testament is Nestle-Aland 1993.

8. Julian wrote of Zeus and Helios as equivalent in a fairly typical triadic Neoplatonic structure, with The One, Zeus, and Helios occupying the three hypostases or realities, with Helios being the high god of the intelligible realm. In the Hymn to King Helios, Julian equated Zeus, Helios, Apollo, and Mithra (Or. 11.132cd, 135d-136a, 144a). Julian's Neoplatonism is recognized as normative by Dillon $(1999,107)$ and Smith (2012, 229-37).

9. Guido $(2000,156)$ points out that Athena in Julian's hands is not extruded from Zeus' head, but taken whole from the whole of him, in essence a replica (cf. Julian Hymn to King Helios, Or. 11.149b). Here, Zeus

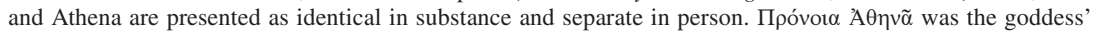
cult title at Delphi and Delos, LSJ 1491, s.v. $\pi \rho$ óvor $\alpha$.

10. See Kelly 1972, 100-130, for the text of the Old Roman Creed, or $R$, in which Christ was described as being born via the Holy Spirit and the Virgin Mary (qui natus est Spiritu sancto ex Maria virgine, tòv

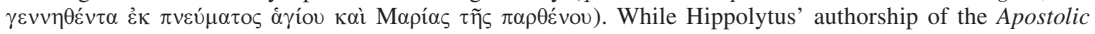
Traditions, primary source of $R$, has recently come under fire, this point regarding the Virgin Birth is also supported by the use of the proto-creed or "Rule of Faith" in other authors, e.g., Irenaeus Adv. haer. 1.10.1 (c. 180 C.E.); Tert. De praescr. haeret. 13 (c. 200 C.E.); Origen De princ. 1.4 (c. 220 C.E.).

11. Cf. John 3:16-17.

12. E.g., Athanassiadi 1981, 133, 197; Nesselrath 2008, 213-14.

13. Simon 1973, 398; cf. Simmons 1996, 69; Rees 2004, 54-55. 
grandson Julian would loyally serve Helios, the god of his grandfather. Julian sought to supplant Constantine, whose apostasy from Helios he saw as the root of the empire's current troubles. Constantine had been publicly praised by Eusebius as a mimetic Christ-figure (De laudibus Constantini 2.2-5), and in our next passage we see that Julian co-opted that characteristic as well. ${ }^{14}$

In response to Heracleios' irreverent use of myth, Julian crafted his own myth, a thinly veiled version of his early life, in which he outlined his personal history and future plans (Or. 7.227c-234c). In Julian's narrative, a rich man (manifestly Constantine) apostatized away from Helios, bringing consequences upon his people. When he died, his nephew (described only as a boy but clearly Julian) ran afoul of one of the heirs, his cousin (Constantius II), who murdered his family and imprisoned him. ${ }^{15}$ The boy was revealed to be the son of Athena the virgin goddess and Helios, whom Julian equated with Zeus. Zeus informed Helios that the youth (Julian) was his

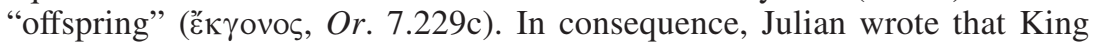
Helios was pleased that in the boy "a small spark of himself was saved" (हैv

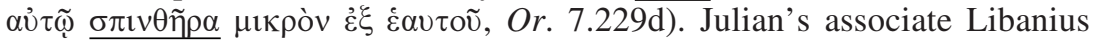
of Antioch responded specifically to the above excerpt when he described young Julian: "There was hidden there a spark of prophetic fire that had

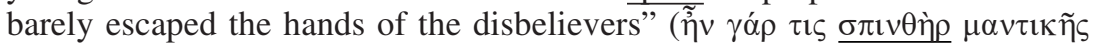

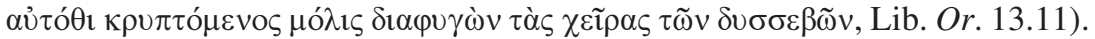
Julian's representative relationship with the divine was strengthened, as he portrayed himself as not only the representative of the gods, but having a special relationship with his personal god, much as did Constantine. While Julian wrote elsewhere that Helios was "the common father of all mankind" (Hymn to King Helios, Or. 11.131c), his treatment in the myth in Oration 7 highlights a special and unique relationship between the god and himself. Julian reinforced this dichotomy, writing that Helios cared for the whole race in common, but created Julian's soul from eternity and made him his follower (Or. 11.157a). It is significant that Julian presented Helios as not only his patron deity, but also the one from whom Constantine had apostatized.

Julian continued, writing: "And Father Zeus commanded motherless Athena

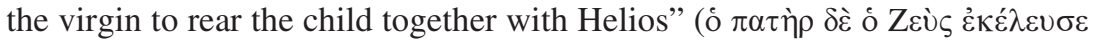

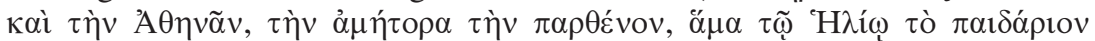
$\dot{\varepsilon} \kappa \tau \rho \varepsilon ́ \varphi \varepsilon ı v, O r .7 .230 a)$. The added relationship to Athena further paralleled Julian's Heracles myth and Christian theology of the virgin mother of God. Julian strengthened this language of "rearing" in a discourse he placed in the

14. It is important to note that Julian was educated by those associated closely with Eusebius, and that Julian evidently knew Eusebius' writings well. Julian's education had been supervised by Eusebius, bishop of Nicomedia and Constantinople, and George, later bishop of Alexandria, two figures chosen by Constantine's son Constantius II and broadly in sympathy with Eusebius' theology. Since Eusebius of Caesarea was a major writer of the previous generation, it is highly likely that Julian was exposed to much of Eusebius' work. We know for certain that Julian was familiar with one work of Eusebius, as in his $C$. Gal. he cited Eusebius' work Praep. evang. Indeed, the nature of Julian's assessment of Eusebius implies a familiarity with the author and his overall work, as the young emperor, a rather harsh reviewer, titled him "the wretched Eusebius" ( $C$. Gal. 222a; Praep. evang. 11.5.5). Bouffartigue (1992, 385-86) has demonstrated the extent of Julian's "direct consultation" of the Praep. evang., showing that he followed Eusebius's argument in his own C. Gal.

15. On scholarly recognition of Julian as the boy, see esp. Smith 1995, 185; for the murders, see Burgess 2008, 5-51. 
mouth of Athena, addressing the boy, shortly thereafter: "Understand, dearest, offspring of myself and of this good god your father!" ( $\mu \alpha \dot{\alpha} v \theta \alpha v \varepsilon \ldots \tilde{\tilde{\omega}} \lambda \tilde{\omega} \sigma \tau \varepsilon$,

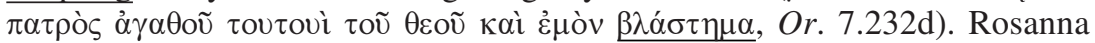
Guido points out that in claiming to be the $\beta \lambda \alpha \dot{\sigma} \sigma \eta \mu \alpha$ of Zeus-Helios, Julian was himself making a claim to be divine. ${ }^{16}$ In this, Julian was following Horace's treatment of Augustus as Heracles (Carm. 3.14.1).

Those who knew Julian well reflected back his rhetoric in their own writings, repeatedly attributing characteristics of Heracles to Julian. Himerius was a Bithynian rhetorician educated at Athens, and an enthusiastic supporter of Julian (Himer. Or. 41.2; Eunap. VS 14.1). ${ }^{17}$ In his oration given in Constantinople in 361, but not in Julian's presence, he claimed to have engaged in Mithraic ritual with the emperor in Constantine's city, equating Mithra, Apollo, and Helios (Himer. Or. 41.1), a synthesis similar to Julian's in his Hymn to King Helios (Or. 11). ${ }^{18}$ Himerius wrote that because of Julian's sharing his nature with Helios, he was able to enlighten people and show them a better way: "After all, one would have expected someone who links

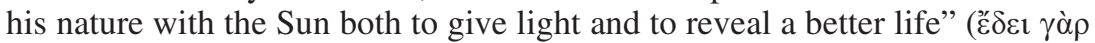

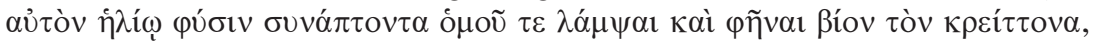
Himer. Or. 41.92-93). ${ }^{19}$

The sophist Eunapius of Sardis, who utilized material from the "detailed memorandum" of Julian's personal physician Oribasius of Pergamon in his Universal History (Eunap. frag. 15 Blockley), confirmed that in his letters,

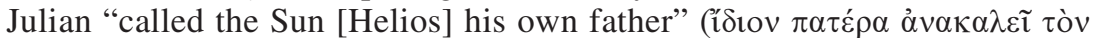
ทं $\lambda$ iov, Eunap. frag. 28.5 Blockley). ${ }^{20}$ Unless we are to consider Julian's letters $(\dot{\varepsilon} \pi \imath \tau \sigma \lambda \alpha i)$ as including his orations, this suggests that what Julian put forth in his public orations about his relationship with Helios also existed in private correspondence to which Oribasius or Eunapius had access. Eunapius emphasized the divine recognition of this special claim to being the son of Helios, who rode his chariot across the heavens, addressing Julian as:

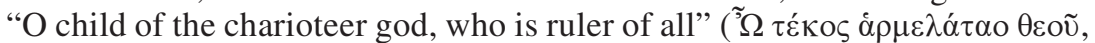
$\mu \varepsilon \delta \varepsilon_{0} \cos \dot{\alpha} \pi \alpha \dot{\alpha} \tau \omega v$, Eunap. frag. 28.4 Blockley). Eunapius also related that when Julian prayed and made sacrifice on his expedition in Persia, he received a prophecy of a glorious end, that following victory over the Persians

16. Guido 2000, xiii: "Qui, lungi dall essene un Pan rustico e deforme, egli si presenta come l'erede legittimo dell'Impero dei Cesari, come $\beta \lambda \alpha ́ \sigma \tau \eta \mu \alpha$ di Helios-Zeus, e dio a sua volta."

17. Jones et al. 1971, 436. The association of Himerius and Julian may have extended farther back than most would assume. Barnes (1987, 209) notes the likelihood that a fragment of an oration of Himerius (frag. 1.6) was given at Sirmium on 15 March 351, with oblique references identifying the presence of Gallus and Julian for Gallus' elevation to Caesar. Himerius also was teaching in Athens in 355 when Julian resided in the city and likely attended his lectures (Socrates Hist. eccl. 4.26.6; Sozom. Hist. eccl. 6.17.1).

18. This equivalency was not unusual, as implied by Mithra's cult title Deus, Sol Invictus Mithras, as well as Julian's similar equivalency; cf. Beck 2006, 5. Penella (2007, 35) notes that Julian was in the city, but not present, as Himerius closed by stating he needed to go and "set eyes upon the emperor."

19. The text of Himerius is that of Colonna 1951, and the translation that of Penella 2007.

20. The text and translation of the fragments of Eunapius are from Blockley 1983. Oribasius was Julian's confidante from the beginning of his quest for the throne through to his death in Persia (Amm. Marc. 25.5.1). Though exiled following Julian's death, he provided Eunapius with the Julianic material for his Universal History, produced in various editions from perhaps as early as 380 C.E. (Bowersock 1978, 8; cf. Baldwin 1975, 85-97). Eunapius clarified that Julian was by no means claiming that Helios had impregnated his mother Basilina, but was asserting divine ancestry as numerous emperors had done before him. 
he would be taken by fiery chariot to his "father's halls of heavenly light" on Olympus (Eunap. frag. 28.6 Blockley). ${ }^{21}$ Again, we see the reference to Julian's heavenly father Helios, familiar from the emperor's pen in Oration $7.230 \mathrm{a}$ and $232 \mathrm{~d}$. While a single instance of such language could be easily dismissed as rhetorical excess for a beloved figure, the entire pattern of such indicates a motif of Julian as Heracles, the deity whom he had crafted into a counterweight to Christ.

To ensure that literate readers did not miss the relationship between the recrafted Heracles and himself, Julian also had the youth enact the part of Heracles in Prodicus' myth of Heracles at the crossroads. The boy fled into the wilderness alone, ${ }^{22}$ where he met Hermes, who told him: "Come, I shall be your guide to a smoother and leveler road, as soon as you have scaled the crooked and steep place where you see all failing and hence heading

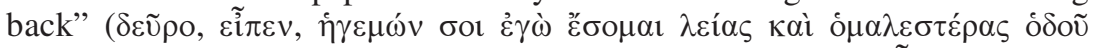

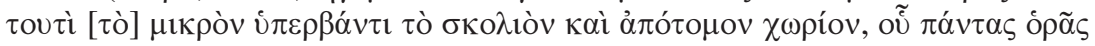

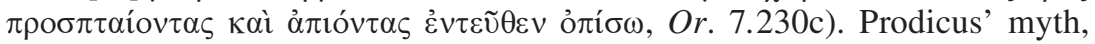
preserved in Xenophon's paraphrase (Mem. 2.21-33), focused upon Heracles' choice between Virtue and Vice, personified by two women, but also metaphorically represented by two paths. ${ }^{23}$ In Julian's myth, the divine messenger Hermes provided the youth guidance at a crossroad where, like Heracles, he had to choose between the easy and the virtuous paths. Therefore, Julian's identification with the newly Christ-like Heracles is due not only to the birth of both to Athena the virgin goddess and Zeus/Helios, but also to Julian's role as the new Heracles who would be the champion of a reinvigorated paganism. ${ }^{24}$ As the youth, Julian was returned to earth by Helios to fulfill his divine mission of cleansing the "impiety" ( $\alpha \sigma \varepsilon \varepsilon \varepsilon \varepsilon \alpha, O r .7 .231 \mathrm{~d})$ of Christianity. ${ }^{25}$ As the panegyrist said about the role of Herculius during Diocletian's reign, Hercules was Jupiter's champion, fulfilling his chosen tasks (Pan. Lat. 3.6-9).

This theme is reflected in the writings of Libanius of Antioch, whose lectures Julian had transcribed for him circa 348, although the two enjoyed a closer association in Antioch only from July 362 onward. ${ }^{26}$ During the one year of their acquaintance, Libanius wrote of Julian as Heracles a number of times. According to Libanius, Julian, who had the soul of a god in the body of a man (Or. 13.47), played Heracles in Gaul to the inferior man Constantius (Or. 12.44), and would someday receive sacrifice and prayer, just as Heracles

21. The hexameter passage, in Blockley's translation: "But having driven the Persian race headlong with your sceptre / Back to Seleucia conquered by your sword, / A fire-bright chariot whirled amidst storm clouds / Shall take you to Olympus freed from your body / And the much-enduring misery of man. / Then you shall come to your father's halls / of heavenly light, from which you wandered / Into a human frame of mortality."

22. Wright $(1913,139)$ noted Julian's parallel of himself here at Or. $7.230 \mathrm{~b}$ with Heracles, isolated, hungry, and facing the elements at Or. 7.219d. Both Rochefort $(1963,63)$ and Guido $(2000,142)$ note that the description of Heracles' poverty and isolation are unique to Julian.

23. The tale of Heracles at the crossroads also appears in Antisthenes frags. 94-97 Caizzi; Cic. Off. 1.118; and in Christian authors such as Justin Martyr 2 Apol. 11.2-5; Basil of Caesarea On the Value of Greek Literature 5.55-77.

24. Wright $(1913,70)$ also sees Julian in this oration as a "second Heracles"; Athanassiadi $(1981,133)$ as "a second Heracles-Mithra."

25. Julian frequently avoided using Christian terminology, but here paralleled Eusebius' frequent refer-

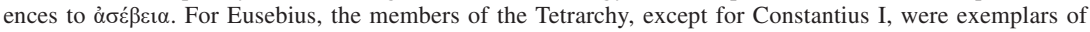
á $\sigma \dot{\beta} \varepsilon ı \alpha$ (Vit. Const. 1.13.2, 1.47.2), a role that Constantine fulfilled for Julian (Caesars, Or. 10.336b).

26. Jones et al. 1971, 505; cf. Lib. Or. 1.51. 
did (Or. 15.36). ${ }^{27}$ However, the key passage in the writings of Libanius is found in his oration on the occasion of Julian's assuming the consulship on 1 January 363. Libanius associated the young emperor with the myth of Heracles at the crossroads, writing that once constraints were removed, this "made him master of will, even as Heracles. Though it was possible to take himself down the smooth way, and there was none to hinder him from carrying himself away to wine, gaming, and flesh, upon the steep and jagged path he

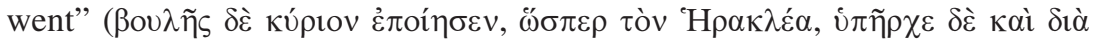

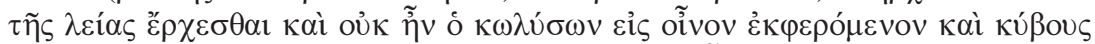


This is recognized by A. F. Norman as a reference to the Prodicus myth of Heracles. ${ }^{28}$ The similarities between this and Julian's myth in Oration 7 are significant. Libanius reflected upon the same scenario, and drew the same conclusion, namely, that Julian, the new Heracles, would make the proper and pious choice. The writings of the rhetorician Libanius of Antioch fulfilled a role for Julian similar to that of Eusebius for Constantine.

These comparisons found purchase with Julian's opponents as well, as demonstrated in two orations by Julian's opponent Gregory Nazianzen in 363-65. Gregory referred to Libanius and those like him as "those worshipping the speech of that man, and recasting him for us as the new god, pleas-



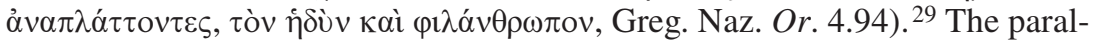
lel did not seem to have escaped the Antiochenes, either, as Gregory noted in several places that when they chose to mock Julian's excessive penchant for sacrifice, they labeled him with one of the epithets of Hercules, "bull burner"

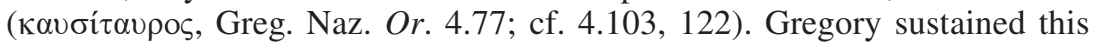
veiled mockery in the conclusion of his Oration 5, a stelographia or proclamation detailing Julian's failures. ${ }^{30}$ Gregory's assertion that his stelae would be "higher and more obvious than the Pillars of Hercules" ( $\tau \tilde{\omega} v$ "H $\rho \alpha \kappa \lambda \varepsilon i ́ \omega v$

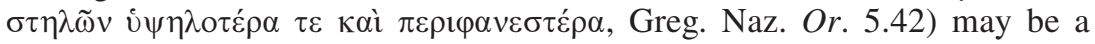
subtle jab in the same vein.

Julian's divine parallels are complicated further by his subtly characterizing himself as Hermes, son of Zeus and the nymph Maia, and the divine guide

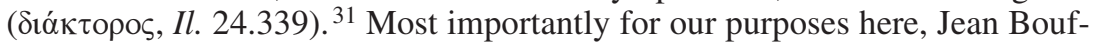
fartigue highlights that Hermes the "master of speech" was associated with the concept of the logos, positioning him as a potential rival to Christ. ${ }^{32} \mathrm{In}$ approximately 342, Julian was removed to remote Cappadocia and reunited with his older half-brother, Gallus (Julian Epistle to the Athenians, Or. 5.271c; Ep. 4.427c; cf. Amm. Marc. 15.2.7, 22.9.4; Lib. Or. 18.12; Sozom. Hist. eccl. 5.2). ${ }^{33}$ Julian described himself at this time being "a mere boy" ( $\mu \varepsilon \iota$ pókıov,

27. Wiemer 1995, 110, 235. The text of Libanius is that of Foerster 1904. Contra Nock 1957, 122-23, Libanius' comparisons appear to be something more than typical emperor worship.

28. Norman $1969,52-53$.

29. The text of Gregory is that of Bernardi 1983.

30. Elm 2012, 346-47.

31. The title is also used at Il. 2.103; 21.497; 24.378, 389, 410, 432, 445; Od. 1.84; 5.43, 75, 94, 145; $8.335,338 ; 12.390 ; 15.319$; and 24.99 .

32. Bouffartigue $1992,649$.

33. The dating of Julian's residence at Macellum in Cappadocia is debated, but I take it as $342-48$. As argued by Norman (1969, ix) Julian's time in Nicomedia coincided with that of Libanius (Lib. Or. 18.13), who 
Epistle to the Athenians, Or. 5.271b). In the Epistle to the Athenians, Julian explained that at some undefined point during his confinement at Macellum he came to understand his family's fate, although with the reintroduction of the older Gallus, I would suggest this happened rather promptly. ${ }^{34}$ Despite his youth, when in To the Cynic Heracleios he portrayed himself contemplating suicide and fleeing into the wilderness, he described himself as follows: "But later, when he became a young man newly bearded, with all the

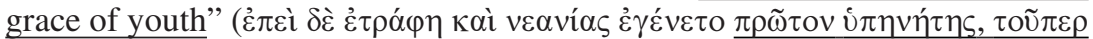

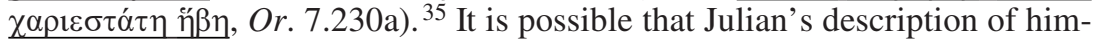
self as newly bearded was an accurate recollection, but rather unlikely given his probable age. ${ }^{36}$ I suggest that his purpose was to use a carefully chosen quotation that opened a window onto Homeric myth. Julian's writing is rich with literary allusions, and here he made use of Homer, his favorite author. In Iliad 24.348, Zeus sent Hermes to Priam, where the god appeared in the likeness of a young prince:

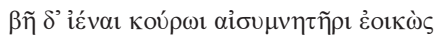

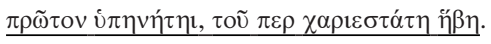

and there took the likeness of a youth, a prince,

newly bearded, with all the grace of youth.

In Odyssey 10.279, Hermes manifested to equip Odysseus for his confrontation with Circe. This was a particularly appropriate conjunction of the two tricksters, one Olympian, one Achaean.

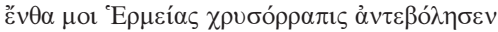

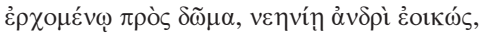

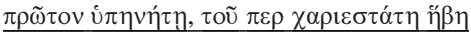

there Hermes with his golden staff met me,

coming to the house, in the likeness of a young man,

newly bearded, with all the grace of youth.

In both epics, the clever Hermes was a representative of the gods sent to guide worthy characters and move the literary action forward. Past scholars have noted the obvious Homeric verbal parallels, but, focusing on physical description, they have not addressed the significance of the function of Julian's quotation within the passage. ${ }^{37}$ This was hardly a popular phrase: it was used by only four authors (aside from Homeric scholia) between Homer and Julian. ${ }^{38}$

came in 344 and departed for Constantinople in 349, but Julian was only of the age of rhetor training at the end of that period, meaning that Julian's six years in Cappadocia must run from 342 to 347-48; Gallus had been at Tralles (Julian Or. 5.271b).

34. Hadjinicolau (1951, 15-22) locates Macellum seven kilometers south of Caesarea.

35. The Greek text of Homer's Iliad is that of West 2000, and of Homer's Odyssey that of von der Mühll 1993.

36. While Julian also had an attachment to his beard in general, as a mark of contrast with the clean-shaven Constantinian dynasty, this is a much more specific reference.

37. E.g., Wright 1913, 137; Rochefort 1963, 78

38. Searching $T L G$ for $\pi \rho \tilde{\tau} \tau$ v $\dot{\pi} \eta \eta v \eta ́ \tau \eta \varsigma$ turns up only four uses between Homer and Julian: Pl. Prt.

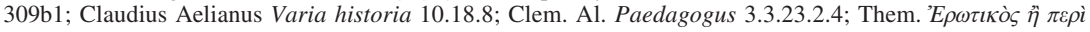
$\kappa \alpha \dot{\lambda} \lambda$ ouৎ $\beta \alpha \sigma \imath \lambda ı \kappa o \tilde{v} 164 \mathrm{~d} 3$. 
Shortly thereafter, Julian makes a play on words marking this identification for the audience, referring to Hermes as being "akin" to himself. Helios and Athena diverted the despondent Julian by casting him into a trance, after which he wandered away into the wilderness. When he rested upon a stone, Hermes the divine guide came to him in auspicious form to lead him to the gods, picking up on Julian's description earlier, at Oration 7.230a: "Therefore, Hermes (being akin to himself, appearing as a young man of the same

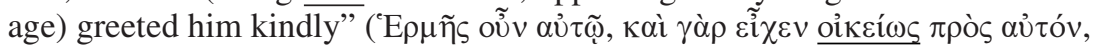

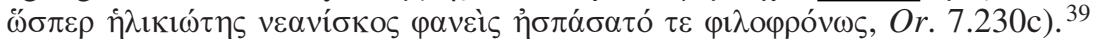
In Julian's portrayal of Hermes as oikeí $\omega \varsigma$ to himself, he employed a double meaning, having just deliberately described himself using Homer's description of Hermes. ${ }^{40}$ Hermes the "young prince" of Iliad 24.348 appeared to the young prince of the house of the descendants of Constantine and led him to his audience with Zeus-Helios with the admonition to "choose the best" ('ँ' ... $\tau \grave{\alpha} \beta \varepsilon ́ \lambda \tau \imath \sigma \tau \alpha$, Or. 7.231a). To listeners with a classical education, Julian

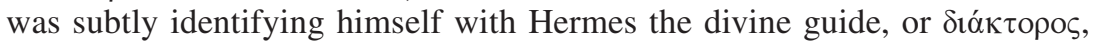
and reinforcing his identification as both the "young prince" and as the chosen one of the Hellenic gods who received their messenger.

At the myth's conclusion, Julian was confirmed in this role as divine guide, as Helios directed the gods to give Julian standards to bear as his symbols of their divine authority. Julian's divine encounter ended with his receiving divine tokens from the gods: the gorgon's breastplate from Athena, a torch

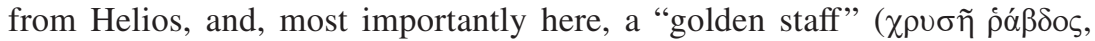
Or. 7.234b) from Hermes. This golden staff of Hermes, sometimes known as the күри́кєıv or caduceus, was a significant component of Hermes' identity, and the source of his title Argeiphontês, as he used it to slay the giant Argus. Julian's self-comparison to Hermes follows the precedent set for the re-creator of the Roman state, Augustus, who was also Mercury/Hermes (Hor. Carm. 1.2.41-44). Thus Julian reinforced his portrayal as the divine guide and, as Rowland Smith described him in this context, the "divine intermediary." 41

By making such an allusion for himself, Julian benefited by reinforcing his consistent presentation of himself elsewhere. In letters to his priests, Ju-

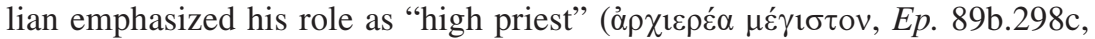
88.451 b), a term equivalent to the Latin pontifex maximus. ${ }^{42}$ In early 362 , Julian also described himself as "having received the direct function of prophecy" from Apollo (Ep. 88.451b). In July 362, Libanius praised Julian for disdaining to wait for oracles, but sitting in the place of the Pythia (Lib. Or. 13.48). Finally, Sozomen recorded that Julian appeared in public images with Hermes, as well as with Ares and with Zeus (Sozom. Hist. eccl. 5.17.3).

Julian's allusive cleverness is meant to lead us to a Homeric framework, one in which he locates himself as a prophetic voice of paganism. In his role

39. In Caesars, Julian claimed it was Hermes who granted him knowledge of his father Mithras, whom Julian equated with Zeus and Helios (Or. 10.336c).

40. Wright $(1913,139)$ recognized the similarity Julian was drawing attention to, but evidently seeing this passage in isolation from the other two I cite, held that Hermes' "affinity" for Julian was because he was "the god of eloquence."

41. Smith $1995,134$.

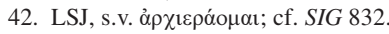


as guide, Hermes would have had appeal for Julian, who was called upon to guide his people back to pagan religion (Julian Or. 7.231d). In fact, although using different terminology, Julian had Helios tasking the young prince with

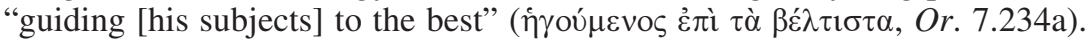
Hermes would also be the divine guide of Julian's Caesares (Or. 10), in which he gave the tale to Julian (10.307a), directed emperors to look to their chosen gods, and directed Julian to follow his father Mithras (10.336a), equated elsewhere with Zeus and Helios. This is a minor motif within a multi-layered myth, but it is a telling one, revealing Julian's desire to portray himself as a divine guide to those with an ear to hear.

In this aspect of Julian's effort to cleanse the impiety of Christianity, he utilized a long lineage of older traditions, combining elements of emperor worship, Sol Invictus worship, and Diocletian's imperial theology. He responded to and recapitulated the Christianized mimetic-ruler theology of Constantine, who had apostatized from Helios. The focus on Constantine and his heirs is clear, since in Julian's myth, Helios told him that the desired cleansing was also of "your ancestral house" ( responded to this, first re-crafting Hercules into a likeness of Christ, then casting himself in the image of Heracles. Julian made use of this literary construct in his campaign to reverse the Constantinian revolution, having Helios give Julian, the new Heracles, a divine commission to purge the impiety instituted by Constantine, the mimetic messiah. Julian positioned himself as an emperor with a divine lineage, made himself the son of a god, and specifically Helios, thereby redressing Constantine's apostasy. While Julian's actions are evidence enough, statements from his contemporaries provide further support, responding as they did to his presentations of Heracles and of himself, portraying Julian as the son of Helios with a human/divine nature, sent to earth by Helios as the healer of the world and recalled to Helios' halls at the end of his life. Coming before his planned invasion of Persia, this was particularly pertinent, given Julian's connection between Alexander the conqueror of the East and Heracles (Julian Caesars, Or. 10.325a). Julian's premature death on the Persian campaign in 363 forestalled further development of his theme, which, had it borne fruit, would have redefined the apologetic battles between Christianity and paganism in the fourth century. To move beyond Christian Lacombrade's assessment that Julian used Heracles as a pagan counter to Christ, Julian not only presented Heracles as a pagan alternative to Christ, but presented himself as a divine avatar, the alternate mimetic ruler diametrically opposed to Constantine. ${ }^{44}$

\section{University of Edinburgh}

43. Compare to Constantine's house-cleaning mission in Vit. Const. 2.55.2.

44. Lacombrade 1964,131

\section{LITERATURE CITED}

Athanassiadi, Polymnia. 1981. Julian and Hellenism: An Intellectual Biography. Oxford. Baldwin, Barry. 1975. The Career of Oribasius. AClass 18: 85-97.

Barnes, Timothy D. 1987. Himerius and the Fourth Century. CP 82: 206-25. 
Beck, Roger. 2006. The Religion of the Mithras Cult in the Roman Empire: Mysteries of the Unconquered Sun. Oxford.

Bernardi, Jean, ed. and trans. 1983. Grégoire de Nazianze, Discours 4-5. Paris.

Blockley, R. C. 1983. The Fragmentary Classicising Historians of the Later Roman Empire. Vol. 2. Liverpool.

Bouffartigue, Jean. 1992. L'empereur Julien et la culture de son temps. Paris.

Bowersock, Glen. 1978. Julian the Apostate. Cambridge, Mass.

Burgess, Richard. 2008. The Summer of Blood: The "Great Massacre" of 337 and the Promotion of the Sons of Constantine. DOP 62: 5-51.

Caizzi, Fernanda, ed. 1966. Antisthenis fragmenta. Milan.

Colonna, Aristide. 1951. Himerii declamationes et orationes cum deperditarum fragmentis. Rome.

Dillon, John. 1999. The Theology of Julian's Hymn to King Helios. Itaca 14-15: 103-15.

Elm, Susanna. 2012. Sons of Hellenism, Fathers of the Church: Emperor Julian, Gregory of Nazianzus, and the Vision of Rome. Berkeley and Los Angeles.

Foerster, Richard, ed. 1904. Libanii Opera. Vol. 2, Orationes XII-XXV. Leipzig.

Guido, Rosanna, ed. and trans. 2000. Giuliano l'Apostate: “Al cinico Eraclio.” Galatina (Lecce). Hadjinicolau, Anne. 1951. Macellum, lieu d'exil de l'empereur Julien. Byzantion 21: 15-22.

Jones, A. H. M., J. R. Martindale, and J. Morris. 1971. The Prosopography of the Later Roman Empire. Vol. 1, A.D. 260-395. Cambridge.

Kelly, J. N. D. 1972. Early Christian Creeds. London.

Lacombrade, Christian, ed. and trans. 1964. L'empereur Julien: Oeuvres complètes. Vol. 2.2. Paris.

Marcone, Arnaldo. 2012. The Forging of a Hellenic Orthodoxy: Julian's Speeches against the Cynics. In Emperor and Author: The Writings of Julian the Apostate, ed. Nicholas BakerBrian and Shaun Tougher, 239-50. Swansea.

Mühll, Peter von der, ed. 1993. Homeri “Odyssea.” Munich.

Nesselrath, Heinz-Günther. 2008. Mit "Waffen" Platons gegen ein christliches Imperium: Der Mythos in Julians Schrift Gegen den Kyniker Herakleios. In Kaiser Julian "Apostata” und die philosophische Reaktion gegen das Christentum, ed. Christian Schafer, 207-19. Berlin.

Nestle, Eberhard, and Kurt Aland, eds. 1993. Novum Testamentum Graece ${ }^{27}$. Stuttgart.

Nock, A. D. 1957. Deification and Julian. JRS 47: 115-23.

Norman, A. F., ed. and trans. 1969. Libanius, Selected Works. Vol. 1, The Julianic Orations. Loeb Classical Library. Cambridge, Mass.

Penella, Robert J., trans. 2007. Himerius: Man and the Word; The Orations of Himerius. Berkeley and Los Angeles.

Rees, Roger. 2004. Diocletian and the Tetrarchy. Edinburgh.

Rochefort, Gabriel, ed. and trans. 1963. L'empereur Julien: Oeuvres complètes. Vol. 2.1. Collection des universités de France. Paris.

Rosen, Klaus. 2006. Julian: Kaiser, Gott und Christenhasser. Stuttgart.

Simmons, Michael Bland. 1996. Arnobius of Sicca: Religious Conflict and Competition in the Age of Diocletian. Oxford.

Simon, Marcel. 1973. Early Christianity and Pagan Thought: Confluences and Conflicts. RelStud 9: 385-99.

Smith, Andrew. 2012. Julian's Hymn to King Helios: The Economical Use of Complex Neoplatonic Concepts. In Emperor and Author: The Writings of Julian the Apostate, ed. Nicholas Baker-Brian and Sean Tougher, 229-37. Cardiff.

Smith, Rowland. 1995. Julian's Gods: Religion and Philosophy in the Thought and Action of Julian the Apostate. London.

West, Martin L., ed. 2000. Homeri “Ilias” XIII-XXIV. Munich.

Wiemer, Hans-Ulrich. 1995. Libanios und Julien: Studien zum Verhältnis von Rhetorik und Politik im vierten Jahrhundert. Munich.

Wright, Wilmer C., ed. and trans. 1913. Julian. Vol. 2. Loeb Classical Library. Cambridge, Mass. 